\title{
A study on ground water quality of industrial area at Gajraula (U.P.), India
}

\section{S. Malik, Pawan Kumar* and Umesh Bharti}

Department of Zoology and Environmental Science, Gurukula Kangri University, Haridwar-249404, INDIA

*Corresponding author. E-mail: pwntyagi0@gmail.com

\begin{abstract}
The present study aims to identify the ground water contamination problem in villages located in the close vicinity of Gajraula industrial area at Gajraula (U.P.), India. Ground water samples were collected from different villages at the depth of 40 and 120 feet from earth's surface layer. Analytical techniques as described in the standard methods for examination of water and waste water were adopted for physico-chemical analysis of ground water samples and the results compared with the standards given by WHO and BIS guidelines for drinking water. Water quality index was calculated for quality standard of ground water for drinking purposes. The present investigation revealed that the water quality is moderately degraded due to high range of seven water quality parameters such as Temperature (18.33-32.36 $\left.{ }^{\circ} \mathrm{C}\right)$, conductivity $(925.45-1399.59 \mu \mathrm{mho} / \mathrm{cm})$, TDS (610.80-923.73 mgL-1), Alkalinity (260.17$339.83 \mathrm{mgL}^{-1}$ ), Ca-Hardness (129.68-181.17 $\mathrm{mgL}^{-1}$ ), Mg-Hardness (94.07-113.50 mgL É1) and COD (13.99-25.62 $\mathrm{mgL}^{-1}$ ). The water quality index (WQI) also indicated the all the water quality rating comes under the standard marginal values (45-64) i.e. water quality is frequently threatened or impaired and conditions usually depart from natural or desirable levels.
\end{abstract}

\section{Keywords: Ground water quality, Industrial pollution, Water quality index}

\section{INTRODUCTION}

In the last three decades, the rapid growth of industrialization and urbanization has created negative impacts on the environment due to industrial, municipal and agriculture wastes containing pesticides, insecticides, fertilizers residues and heavy metals. Several industries are being establishes day by day due to meet the complex the requirement of rapid growing urbanization, consumerization and increase the demand of product in the modern time (Sastry and Rathee, 1999). In modern industrialization period, the most of water resources have affected enormously by seepage, leaching and mixing of industrial effluents in most of the metropolitan cities and industrial townships.

Gajraula, being a prominent industrial area of western Uttar Pradesh, owes its significance to diverse group of industries, which includes large distillery and its associated chemical units, paper, phosphate fertilizer plant, textiles, pharmaceuticals, dairy and other units. The industrial effluents contain toxic chemicals, hazardous compounds, suspended solids and nonbiodegradable materials. The major source of surface and ground water pollution is injudicious discharge of untreated industrial effluents directly into the surface water bodies resulting in surface and ground water pollution (Nasrullah, et al., 2006). The effluents from the industries and sewage of industrial towns have drained collectively through a local drain known as Bagad nallah, which assumes the shape of seasonal river, especially during monsoon. The quality of Bagad river water is a great concern to deteriorate the quality of the surface water and ground water due to releasing their effluent without any adequate treatment and polluting the upper water table through the leaching process in and around industrial area. The ground water quality of selected four village located around industrial area have been affected a lot and causes serious disease among the human beings and other livestock population. The industrial effluents if not treated properly controlled, can pollute and cause serious damage to the ground water resources (Olayinka, 2004).

Water quality index (WQI) has provided an assessment of water quality trends for management purpose even though it is not meant especially as an absolute measure of the degree of pollution or the actual water quality (Anonymous, 1997). WQI is calculated from the point of view of the suitability of ground water for human consumption (Ramakrishnaiah, et al., 2009).

The present study is aimed to assess the ground water quality in and around Gajraula industrial area at Gajraula (U.P.).

\section{MATERIALS AND METHODS}

Gajraula city is approximately $115 \mathrm{Km}$. away from Delhi on national highway NH-24, Delhi-Lucknow road. Gajraula is well known and one of the oldest industrial area of district J.P. Nagar (Uttar Pradesh) situated on globe at a longitude $78^{\circ} 13^{\prime} 48.75^{\prime \prime} \mathrm{E}$ and latitude $28^{\circ}$ 50 '59.26" N at 679 feet above sea level (207 msl). Gajraula industrial area about $6.0-11.5 \mathrm{~km}$ covering surface area 


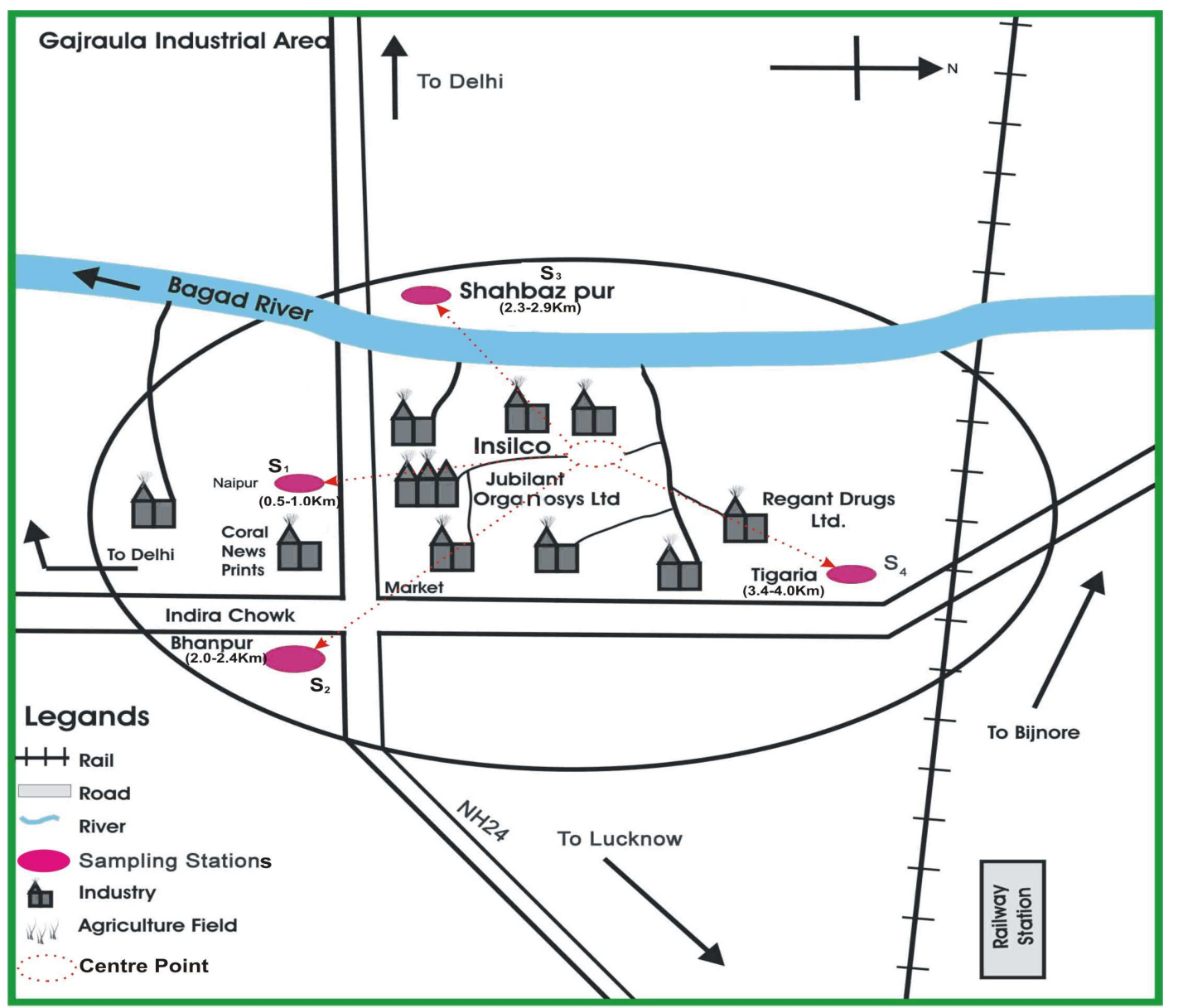

Fig. 1. Showing sampling sites at Gajraula industrial Area (Not to Scale).

was selected on the basis of existence of large number of industries (chemical units, pulp \& paper, phosphate fertilizer plant, textiles, pharmaceuticals, dairy products processing units and others), which discharge a huge amount of wastewater in the form of mixed effluents through different drains into a seasonal river Bagad. Ground water samples were collected by grab sampling method from hand pumps and bore well having the water table at depth of 40 feet and 120 feet respectively, from sampling sites selected at four villages located nearby Gajraula industrial area namely, Naipur $\left(S_{1}\right)$ Bhanpur $\left(S_{2}\right)$, Shahbazpur $\left(\mathrm{S}_{3}\right)$ and Tigaria $\left(\mathrm{S}_{4}\right)$, during summer, monsoon and winter seasons (April 2008 to March-09). The distances of villages from the outgoing industrial effluent drains were as $\mathbf{S}_{1}-0.5-1.0 \mathrm{Km}, \mathbf{S}_{2}-2.0-2.4 \mathrm{Km}, \mathbf{S}_{3}$ 2.5-2.9 Km, $\mathbf{S}_{4}-3.4-4.0 \mathrm{Km}$. approximately, located in close vicinity of industrial zone (Fig. 1).

The ground water samples $(\mathrm{n}=05)$ were collected from each of hand pumps (HP no.-5) and bore wells (BW no.5) from each sampling sites during the particular seasons. The water samples were analyzed by standard methods (APHA, 1998 and Trivedi and Goel, 1984). The results were compared with standard given by WHO (2004) and
BIS (IYYI). The seeding water method was used to determine the BOD. Water quality index was calculated on the basis of fifteen physico-chemical parameters according to CCME water quality indexing critarion (2001).

\section{RESULTS AND DISCUSSION}

The present study showed that the how much is the acceptable ground water quality of hand pumps and bore wells of four villages compared with drinking water standards. The results of physico-chemical characteristics of ground water are presented in Table- 1 . The temperature of the water is closely related with dissolved oxygen, hence water of low temperature containing higher value of dissolved oxygen and low value of BOD and COD. Temperature of ground water ranged from $18.33-32.36^{\circ} \mathrm{C}$ in bore well and hand pump water at $\mathrm{S}_{4}$ and $\mathrm{S}_{1}$ respectively during winter and summer season. $\mathrm{pH}$ value varied between range as 7.25-8.05, minimum and maximum $\mathrm{pH}$ were recorded in hand pump and bore well water at $\mathrm{S}_{1}$ and $\mathrm{S}_{2}$ during winter and monsoon season respectively. $\mathrm{pH}$ values of all water samples were within the permissible limit given by WHO. Electrical conductivity with regards to water quality 

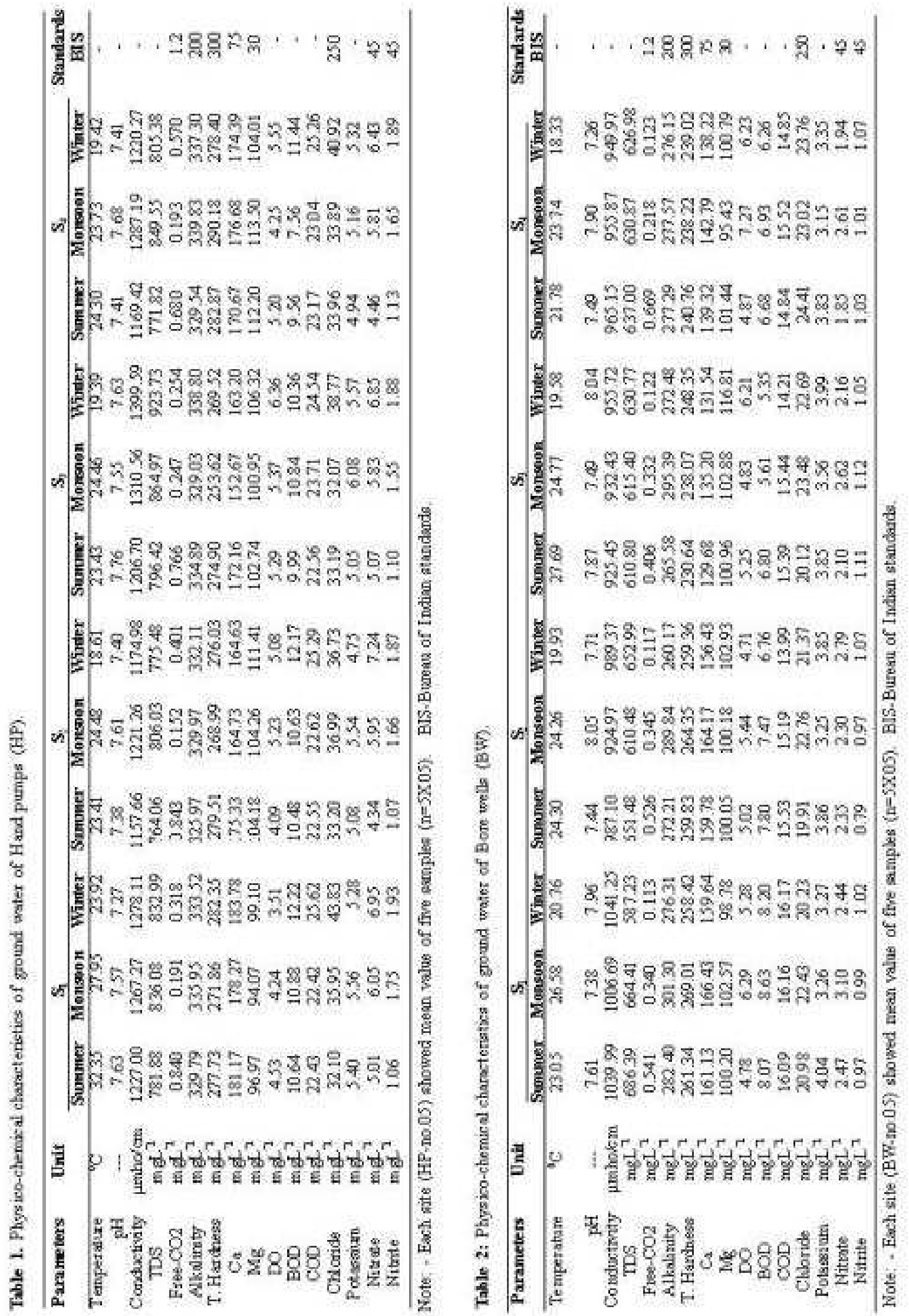
referred to the amount of salts in the water and is a numerical expression of the ability of an aqueous solution to convey an electric current. It is also an approximate indicator of total dissolved ions such as heavy metals and widely used for pollution monitoring (Nasrullah, et al. 2006). The values of conductivity of ground water of bore well and hand pumps ranged from 925.45-1399.59 $\mu \mathrm{mho} / \mathrm{cm}$ at $\mathrm{S}_{3}$ during summer and winter season respectively. Total dissolved solids exhibited turbid condition of water pollution strength. The values of total dissolved solids in ground water ranged from 610.80-923.73 mg/l, lowest and highest values of TDS were recorded in bore well and hand pump water at $S_{3}$ during summer and winter season respectively. Drinking water with high total dissolved solids generally showed inferior potable quality and induced an unfavorable physiological reaction in the transient consumer and gastrointestinal infections. (Kulshrestha, et al., 2002) also observed the similar range $(840-1050 \mathrm{mg} / \mathrm{l})$ of total dissolved solids in tube well water during summer season. Free $\mathrm{CO}_{2}$ in ground water ranged from 0.113 $0.843 \mathrm{mg} / \mathrm{l}$, while the lowest and highest value of free $\mathrm{CO}_{2}$ in bore well and hand pumps water was recorded at $\mathrm{S}_{1}$ and $\mathrm{S}_{2}$ during winter and summer season respectively. All the values of free $\mathrm{CO}_{2}$ were within the permissible limit given by BIS. Alkalinity of water is strongly correlated with $\mathrm{pH}$ value, if $\mathrm{pH}$ of water sample is also high than alkalinity, if $\mathrm{pH}$ value low than alkalinity, it may shown lower trend. Alkalinity in ground water was recorded in the ranged between $260.17-339.83 \mathrm{mg} / \mathrm{l}$ in bore well and hand pump water at $\mathrm{S}_{2}$ and $\mathrm{S}_{4}$ during winter and monsoon season respectively. Water with more than $200 \mathrm{mg} / \mathrm{l}$ value of alkalinity is not permissible for drinking as per WHO. The present values of alkalinity have shown higher mark on permissible limit for potability of drinking water quality and contributed for degradation of ground water resources.

The high degree of water hardness can definitely be attributed to the disposal of untreated and improperly treated sewage and industrial wastes (Shanker, et al., 2008). Total hardness of ground water samples were recorded in the ranged between $230.64-290.18 \mathrm{mg} / \mathrm{l}$ in bore well and hand pump water at $\mathrm{S}_{3}$ and $\mathrm{S}_{4}$ during summer and monsoon season respectively. The values of Ca-Hardness in ground water varied between 129.68$181.17 \mathrm{mg} / \mathrm{l}$ in bore well and hand pump water at $\mathrm{S}_{3}$ and $\mathrm{S}_{1}$ during summer seasons. The similar trend of calcium hardness occurred in ground water also reported by Ramakrishnaiah, et al., (2009) and significantly correlated hardness of drinking water with health of humanbeings. $\mathrm{Mg}$ - Hardness in ground water was recorded in the ranged between $94.07-113.50 \mathrm{mg} / \mathrm{l}$ in hand pump water at $\mathrm{S}_{1}$ and $\mathrm{S}_{4}$ during monsoon season respectively.

Dissolved oxygen in ground water samples were recorded in the ranged between 3.51-6.38 mg/l in hand pump water at $S_{4}$ and $S_{3}$ during winter season respectively. The lower value of DO (3.5) at site-S1 during winter season may be due to the lowest distance (500 meter) from the outgoing industrial drain which indicates organic pollution in water due to percolation of effluent containing soluble organic compounds and enhanced value 5.23 in monsoon due to the rainfall i.e. percolation of rain water towards ground water affects the ground water quality. Similarly enhanced value of DO 6.3 at $\mathrm{S}_{3}$ and 5.5 at $\mathrm{S}_{4}$ may be due to the higher distance 2-3 and 3$4 \mathrm{Km}$ far from the outgoing industrial effluent drains. The difference between DO value in hand pump water and bore well water were found due to the depth level of ground water, bore wells( deep water) having a least pollution in comparison to hand pump (shallow water). In case of $\mathrm{S}_{3}$ shown fluctuations in DO values in different seasons may be due to the depth of hand pump and bore well water. All the values of dissolved oxygen recorded under the permissible limit 3.0-14.0 mg/l given by WHO. Biochemical oxygen demand (BOD) is inter-related with the levels of dissolved oxygen in the water. Organic compounds such as carbohydrates, proteins and fats, which can be a result of urban run-off, domestic sewage and industrial effluent are broken down by the microorganisms present in the water and exerted an oxygen demand in aquatic system (Efe, et al., 2005). BOD values in water were recorded in the ranged between 6.26-12.22 $\mathrm{mg} / \mathrm{l}$ in bore well and hand pump water at $\mathrm{S}_{4}$ and $\mathrm{S}_{1}$ during winter season respectively. Chemical oxygen demand (COD) represent the amount of required for microbial decomposition of organic matter. Amount of oxygen required for chemical decomposition of organic matter were recorded in the ranged between $13.99-25.62 \mathrm{mg} / \mathrm{l}$ in bore well and hand pump water at $S_{2}$ and $S_{1}$ during winter season respectively. All the values of COD recorded high comparison than standard value $(10 \mathrm{mg} / \mathrm{l})$ given by WHO. The dissolved oxygen, BOD and COD have not favored the permissible value of drinking water quality, which existed in ground water of villages located near to industrial area. Hence, the existed drinking water has been contaminated by the leaching industrial effluents and intermixing with ground water table.

Chloride values of ground water were varied from 19.91$43.83 \mathrm{mg} / \mathrm{l}$ in bore well and hand pump water at $\mathrm{S}_{2}$ and $\mathrm{S}_{1}$ during summer and winter season respectively. Excessive chloride imparts bitter taste to water and corrode steel and may cause cardio-vascular problem. Potassium in ground water samples shown ranged from 3.19-6.08 mg/ 1 in bore well and hand pump water at $\mathrm{S}_{4}$ and $\mathrm{S}_{3}$ during monsoon season respectively. The values of potassium were recorded in the range of permissible limit (WHO). Nitrate values in ground water samples ranged from 1.85$7.24 \mathrm{mg} / \mathrm{l}$ in bore well and hand pump water at $\mathrm{S}_{4}$ at $\mathrm{S}_{2}$ 
during summer and winter season respectively. Water with more than $45 \mathrm{mg} / \mathrm{l}$ of nitrate is not permissible for drinking as per WHO and limit is mandatory. Beyond this, it may cause metheamoglobinemia or blue baby disease in infants. It may also be carcinogenic in adults (Basappa, 2003). Nitrite values in ground water samples were recorded in the ranged between $0.79-1.93 \mathrm{mg} / \mathrm{l}$ in bore well and hand pump water at $S_{2}$ and $S_{1}$ during summer and winter season respectively. All the values of nitrite come under the standard value given by WHO.

Water quality index calculated on the basis of existed seasonal physico-chemical characteristics of ground water in all sampling sites. WQI ratings were measured in the range of 54.97-57.58 on $\mathrm{S}_{1}$ site, lowest and highest value of WQI in hand pump and bore well water recorded during monsoon and winter season respectively. WQI ratings were measured in the ranged from 55.93-57.94 on $\mathrm{S}_{2}$ site, the lowest and highest value was recorded in hand pump and bore well water during monsoon and winter season respectively. Water quality ratings were calculated in the ranged from 55.55-57.88 on $\mathrm{S}_{3}$, the minimum and maximum value of WQI recorded in hand pump and bore well water during winter season seasons respectively. WQI ratings were recorded in the range from 55.40-58.28 on $\mathrm{S}_{4}$, minimum and maximum WQI values recorded in hand pump and bore well water during monsoon and winter season respectively. Water quality indexing values come under the marginal category in drinking water of hand pump and bore well at all sampling sites i.e. water quality is frequently threatened or impaired; conditions usually depart from natural or desirable levels. The present WQI clearly indicated that ground water quality of hand pumps at the depth 40 feet is slightly critical than ground water quality of bore well at 120 feet depth from water table (Table -2).

The overall observation of present study indicated deterioration trend of ground water quality in the available water table on sampling areas due to lack of waste water treatment facilities in all industries These industries have not fulfilled the norms of pollution controlling authorities such as central pollution control board, New Delhi and state pollution control board. Such types of industrial water pollution problems mainly concerned by lack of environmental ethics, lack of financial resources and non-adoption of environmental laws at the corporate level. The ground water resources must be non-contaminated, purified and treated efficiently on sustainable basis at point and non point sources of pollution level. The drinking water quality should be properly maintained and be available for human society to get healthy longer life.

\section{ACKNOWLEDGEMENT}

The authors are thankful to Prof. A.K Chopra, Dean,
Faculty of Life Science, Prof. B.D. Joshi, Co-ordinator of UGC (SAP) and Prof. D. Bhatt, Head, Department of Zoology and Environmental Science for the facilities provided to carry out the work successfully. The author (Pawan Kumar) gratefully acknowledges the financial support from UGC, Delhi.

\section{REFERENCES}

Anonymous (1997). A Hach. Water Analysis Handbook. 3rd Edn USA: Hach Company.

APHA (1998).Standard methods for the examination of wastewater, American Public Health Association, Washington, D.C. pp. 1190.

Basappa, R. M. (2003). Status of ground water quality in Bangalore and its environment. Report, Department of Mines and Geology, Bangalore.pp.156

BIS (1991). Bureau of Indian Standards IS: 10500, Manak Bhavan, New Delhi, India.

Brown, R. M.; McLelland, N.; Deininger, R. A. and O'Connor, M. F. (1972). A water quality index, crashing the psychological barrier. Indicators of Environmental Quality. pp.455

CCME (2001). Canadian Water Quality Index, 1.0 (Drinking water quality manual), pp.4

Efe, S. I.; Ogban, F. E.; Horsfall, M. J. and Akporhonor, E. E. (2005). Seasonal variation of physico-chemical characteristics in water resources quality in western Niger Delta Region, Nigeria. J. Appl. Sci. Environ. Mgt. 9(1):191195.

Kulshrestha, S., Dhindsa, S. S. and Singh (2002). Physicochemical characteristics of underground water and effluent water in Sanganer town of Jaipur City during pre-monsoon season. Nature Environment and Pollution Technology. 1(4):453-456.

Nasrullah., Naz, R.; Bibi, H.; Iqbal, M. and Durrani, M. I. (2006). Pollution load in industrial effluent and ground water of Gadoon Amazai Industrial Estate (GAIE) Swabi, NWFP. Journal of Agriculture and Biological Science, 1(3):18-24.

Olayinka, K. O. (2004). Studies on industrial pollution in Nigeria- the effect of textile effluents on the quality of groundwater. Nigerian Journal of Health and Medical Sciences, 3:44-50.

Ramakrishnaiah, C. R.; Sadashivaiah, C. and Ranganna, G. (2009). Assessment of water quality index for the ground water in Tumukpur taluk Karnataka state, India. E. J. of Chem. 6(2):523-530.

Sastry, K.V. and Rathee, P. (1999). Ground water quality in three villages of Rohtak district. J. Natcon. 11(2): 175-182.

Shanker, B.S.; Balasubramanya, N. and Reddy, M. T. M. (2008). Impact of industrialization on ground water quality- a case study of Peenya industrial area, Bangalore, India. Environ. Monit. Assess. 142:263-268.

Trivedi, R.K. and Goel, P.K. (1984). Chemical and biological methods for water pollution studies, Environmental Publication, Karad, India, pp. 251.

WHO (2004). Guidelines for Drinking Water Quality. Vol.1-4, Geneva, pp. 515. 